\title{
PEMANFAATAN MODEL ENTERPRISE ARCHITECTURE PADA E-ACADEMIC POLITEKNIK HARAPAN BERSAMA
}

Ginanjar Wiro Sasmito

D IV Teknik Informatika / Politeknik Harapan Bersama

Jln. Mataram No. 09 Kota Tegal

anjar.dosen@gmail.com

\begin{abstract}
Abstrak - Pemanfaatan E-Academic dengan teknologinya saat ini belum selaras dengan kebutuhan Politeknik Harapan Bersama yang sebenarnya, sehingga memungkinkan penerapan e-academic tersebut saling tumpang tindih. Kebutuhan pada Politeknik Harapan Bersama tersebut hanya mampu dijawab dengan memperhatikan faktor integrasi didalam pengembangnnya, tujuan integrasi yang sebenarnya adalah untuk mengurangi kesenjangan yang terjadi dalam proses pengembangan sistem. Untuk menurunkan kesenjangan tersebut, maka diperlukan sebuah paradigma dalam merencanakan, merancang, dan mengelola sistem yang disebut dengan enterprise architecture. Salah satu model enterprise architecture adalah framework TOGAF. Pemodelan Enterprise Architecture framework TOGAF dapat menghasilkan blue print pada sebuah sistem yang terintegrasi, mempercepat pendistribusian atau penyebaran informasi sehingga lebih efektif dan efisien.
\end{abstract}

Kata kunci - Enterprise Architecture, Framework Togaf, E-Academic

\section{PENDAHULUAN}

Semakin meningkatnya kebutuhan dalam fungsi institusi menyebabkan pemanfaatan media dalam menyebarkan informasi dalam institusi menjadi sangat dibutuhkan, demikian pula pada institusi pendidikan yaitu Politeknik Harapan Bersama. Pemanfaatan $e$ academic pada Politeknik Harapan Bersama khususnya di Prodi D IV Teknik Informatika belum selaras dengan kebutuhan Politeknik Harapan Bersama yang sebenarnya, sehingga memungkinkan pemanfaatan e-academic tersebut menjadi tumpang tindih.Kondisi tersebut dapat membuat e-academic tidak dapat dimanfaatkan secara maksimal sesuai dengan yang diharapkan berdasarkan misi dan tujuan penerapan sistem, yaitu efesiensi dan efektifitas dalam pemenuhan kebutuhan organisasi, mulai dari pemenuhan kebutuhan pada level yang tertinggi dalam organisasi sampai pada kebutuhan paling bawah yaitu kebutuhan operasional.

E-Academic merupakan sebuah media berbasis website yang digunakan untuk menyebarkan informasi akademik pada Politeknik Harapan Bersama. Eacademic dikembangkan dengan menerapkan metode rekayasa sistem berbasis komputer berdasarkan prinsip-prinsip siklus pengembangan sistem SDLC (System Development Life Cycle) dengan rekayasa sistem waterfall [1].

Kebutuhan Politeknik Harapan Bersama hanya mampu dijawab dengan memperhatikan beberapa faktor dalam penerapan sistem, salah satu faktor tersebut adalah integrasi didalam pengembangnnya, tujuan integrasi yang sebenarnya adalah untuk mengurangi kesenjangan yang terjadi dalam proses pengembangan sistem. Untuk menurunkan kesenjangan tersebut, maka diperlukan sebuah paradigma dalam merencanakan, merancang, dan mengelola sistem informasi yang disebut dengan enterprise architecture.

Enterprise architecture merupakan basis pengetahuan yang terdiri dari elemen lingkungan bisnis internal dan eksternal serta hubungan antara keduanya [2]. Dengan semakin meningkatnya persyaratan untuk kelancaran dan keselarasan sistem bisnis, enterprise architecture telah menjadi bidang yang penting [3] dan telah menarik perhatian banyak peneliti, ahli IT serta pelaku beragam bisnis lainnya [4].

Terdapat beragam model enterprise architecture, tetapi pada penelitian ini digunakan model enterprise architecture framework TOGAF, dikarenakan didalam framework TOGAF terdapat metode dan tools yang detil untuk proses implementasi [5]. TOGAF (The Open Group Architecture Technique) merupakan suatu framework terperinci dan alat pendukung untuk mengembangkan satu arsitektur enterprise yang dipergunakan dengan bebas oleh organisasi apapun yang mengembangkan untuk mendisain, evaluasi, dan membangun blueprint TI [6].

Dengan pemanfaatan enterprise architecture framework TOGAF maka dapat menghasilkan model dan kerangka dasar (blue print) dalam mengembangkan sebuah $e$-academic yang terintegrasi sehingga dapat memenuhi kebutuhan Politeknik Harapan Bersama.

Penelitian serupa yang berkaitan dengan penerapan Enterprise Architecture menggunakan framework TOGAF diantaranya :

Analisa penerapan TOGAF dalam bagian akademik STMIK Bumigora Mataram memberikan gambaran apakah penerapan arsitektur enterprise pada bidang akademik di STMIK Bumigora Mataram sudah dijalankan dan apa kendala yang dihadapi 
dalam penerapan arsitektur enterprise. Penelitian ini menggunakan metodologi TOGAF ADM dalam merancangan arsitektur enterprise dan data yang diperoleh dalam penelitian ini dikumpulkan melalui wawancara, observasi dan dokumentasi yang berkaitan dengan penerapan arsitektur enterprise di akademik STMIK Bumigora Mataram. Keluaran yang dihasilkan berupa sebuah framework arsitektur enterprise yang dapat dijadikan bahan untuk mencapai tujuan strategis. [7].

Penyusunan Enterprise Arsitektur juga dilakukan pada PT. Pelabuhan Indonesia III (Persero) yang merupakan Badan Usaha Milik Negara yang bergerak di sektor transportasi. EAP (Enterprise Architecture Planning) adalah rencana yang menerjemahkan visi dan strategi bisnis ke perusahaan yang efektif dengan menciptakan, mengkomunikasikan, meningkatkan persyaratan utama, prinsip-prinsip dan model bisnis, data, aplikasi, teknologi yang menggambarkan masa depan perusahaan dan evolusinya. Untuk mengembangkan EAP PT. Pelindo III (Persero) menggunakan kerangka The Open Group Architecture Framework (TOGAF). TOGAF dipilih karena dapat memberikan metode pengembangan arsitektur yaitu metode pengembangan arsitektur (ADM). Jadi, masalah dalam penelitian ini adalah bagaimana menyusun perencanaan arsitektur enterprise menggunakan TOGAF. Hasil dari penelitian ini adalah cetak biru dari IS / IT sebagai pedoman perusahaan pengembangan / IT. Blueprint dokumen SI / TI ada meliputi: arsitektur awal, prinsip-prinsip arsitektur, manajemen persyaratan, visi arsitektur, arsitektur bisnis, arsitektur sistem informasi, arsitektur teknologi, rencana migrasi, tata kelola dan mengubah arsitektur manajemen [8].

Pemodelan Enterprise Architecture juga diterapkan pada Sistem Informasi Rencana Kinerja Tahunan Sekretariat DPRD Provinsi Jawa Tengah dengan Menggunakan Framework Togaf. Pemodelan Enterprise Architecture framework TOGAF dapat menghasilkan blue print pada sebuah sistem informasi rencana kinerja tahunan yang terintegrasi, mempercepat proses pelaporan rencana kinerja tahunan kepada pimpinan (Sekretaris DPRD Provinsi Jawa Tengah) sehingga lebih efektif dan efisien [9].

Penggunaan Framework TOGAF juga diterapkan untuk pemodelan Sistem Informasi Akademik pada institusi XYZ. Institut XYZ merupakan institusi kepamongprajaan di lingkungan Departemen Dalam Negeri yang membantu menteri dalam melaksanakan program pendidikan vokasi, akademik, dan profesi di bidang kepamongprajaan. Dalam menunjang kegiatan organisasi untuk fungsional akademik digunakanlah Sistem Informasi Akademik (SIAKAD). Sistem informasi harus dirancang dengan baik sesuai dengan perencanaan sistem agar tidak terjadi kegagalan dan masalah dalam sistem yang disebabkan tidak adanya perencanaan sistem yang jelas, dan teknologi informasi yang dapat mendukung jalannya sistem informasi tersebut. Untuk menciptakan keselarasan strategi bisnis dan teknologi informasi organisasi dirancang sebuah enterprise architecture. Perancangan enterprise architecture untuk SIAKAD di institut XYZ menggunakan framework TOGAF ADM. TOGAF ADM bersifat fleksibel, interaktif dan detail serta cocok diimplementasikan untuk organisasi yang belum memiliki EA. Business Architecure merupakan fase ke tiga dalam TOGAF ADM yang berfungsi untuk mendefinisikan arsitektur baseline, menentukan model bisnis dan merancang arsitektur target yang nantinya akan menghasilkan sebuah blueprint arsitektur sebagai dasar pembangunan dan pengembangan sistem informasi akademik (SIAKAD) di institut XYZ. [10].

Perencanaan Infrastruktur Teknologi Informasi menggunakan Framework TOGAF juga diterapkan pada Lembaga Penelitian UIN Syarif Hidayatullah. Keberadaan infrastruktur teknologi informasi yang adaptif mutlak dibutuhkan di setiap perusahaan atau organisasi demi keberlangsungan proses bisnis yang dimilikinya. Lemlit (Lembaga Penelitian) merupakan salah satu unsur pelaksana akademik di UIN Syarif Hidayatullah Jakarta yang bertugas menyelenggarakan pembinaan dan pengembangan penelitian berbagai bidang. Perencanaan infrastruktur teknologi informasi ini dirasa sangat perlu karena keadaan Lemlit masih kurang optimal dari segi teknologi informasinya. Dari perencanaan infrastruktur teknologi informasi menggunakan TOGAF ADM ini dihasilkan dokumentasi infrastruktur teknologi informasi berupa 5 fungsi bisnis dengan 25 entitas data dan 14 aplikasi yang dapat diusulkan kepada pihak Lemlit dan diharapkan bisa menunjang proses bisnis yang ada di Lemlit serta membantu dalam pencapaian visi misinya[11].

\section{METODE}

\section{A. Kerangka Permasalahan}

Dukungan sebuah E-Academic pada Politeknik Harapan Bersama yang berkualitas merupakan suatu keharusan dikarenakan demi efektivitas, validitas dan reliabilitas informasi yang dihasilkan berdasarkan atas data yang telah diinputkan. Keadaan seperti itulah yang mengharuskan Politeknik Harapan Bersama untuk membuat sebuah model arsitektur yang lebih baik.

Tahun 2015 pengembangan E-Academic pada Politeknik Harapan Bersama telah dilakukan dengan memanfaatkan teknologi intranet. Namun dalam implementasinya masih banyak kendala dikarenakan tidak semua menu pada website e-academic tersebut memiliki akun dan data yang sama, seperti pada menu e-college, Jurnal Online, Sistem Informasi Tugas Akhir, Sistem Informasi Kerja Praktik dan Sistem Informasi Alumni sehingga proses integrasi data tidak dapat berjalan dengan baik dan maksimal. Bahkan selaku pimpinan pada institusi Politeknik Harapan Bersama tidak dapat mengetahui dan mendapatkan 
pelaporan mengenai penggunaan sistem pada menu yang terdapat pada e-academic dengan cepat dikarenakan integrasi data pada e-academic belum dapat terealisasi dengan baik.

\section{B. Permasalahan E-Academic}

Pengembangan e-academic perlu ditindak lanjuti

Page|121 dengan upaya pemeliharaan database, peningkatan software, evaluasi kinerja serta pemanfaatan $e$ academic dalam menunjang penyebaran informasi akademik pada Politeknik Harapan Bersama. Pemeliharaan database dapat dilakukan dengan pemutakhiran dan validasi data. Peningkatan software e-academic harus disesuaikan dengan sistem yang ada, kebutuhan pengguna, dan perkembangan teknologi yang semakin cepat perubahannya serta evaluasi kinerja $e$-aademic.

\section{Kerangka Penelitian}

Dalam mengembangkan e-academic, keseluruhan proses yang dilalui harus melalui beberapa tahapan. Tahapan tersebut meliputi perencanaan sistem yang sesuai dengan kebutuhan pengguna, analisis sistem, perancangan sistem, implementasi sistem, dan pemeliharaan sistem. Keluaran dari perencanaan sistem dihasilkan persyaratan yang sesuai dengan kebutuhan pengguna. Analisis dan perancangan sistem menghasilkan spesifikasi perancangan logik dan teknis dari implementasi sistem dihasilkan perangkat lunak yang dapat digunakan, serta dari pemeliharaan sistem dihasilkan aplikasi yang sudah teruji dan siap dioperasionalkan [12]. Berdasarkan atas tahapan penelitian tersebut, maka langkah penelitian dapat dilihat pada kerangka penelitian sebagai berikut :

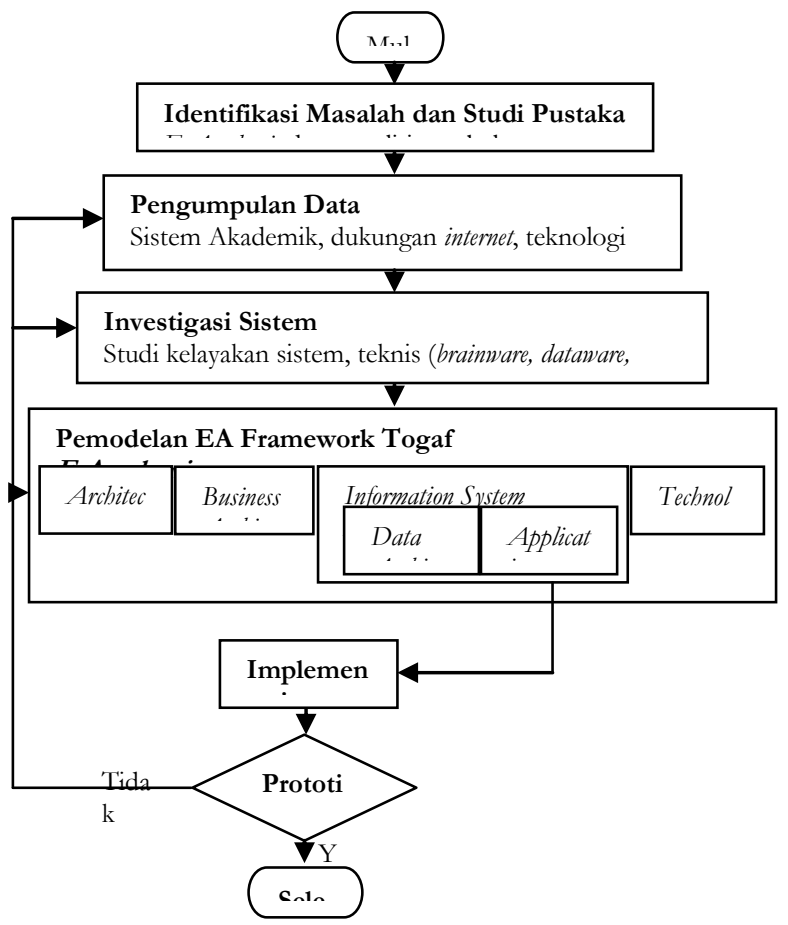

\section{HASIL DAN PEMBAHASAN}

\section{A. Analisis Arsitektur Teknologi}

Dalam menganalisis arsitektur teknologi perlu adanya identifikasi prinsip-prinsip platform teknologi yang mendasari pemilihan suatu platform. Pada penelitian ini akan dilakukan identifikasi prinsip platform teknologi dengan menggunakan 7 (tujuh) area agar identifikasi lebih fokus. Ketujuh area tersebut adalah sebagai berikut :

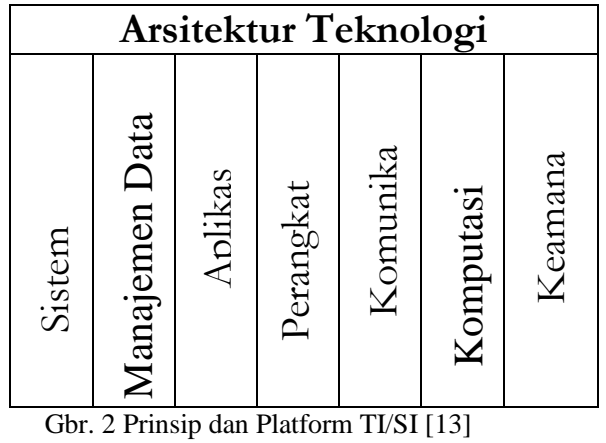

Gambar 2 tersebut dapat dijelaskan sebagai berikut :

a. Sistem Operasi

Berdasarkan kebutuhan sistem yang telah dianalisis, maka pada penelitian ini diusulkan dalam pengembangan e-academic Politeknik Harapan Bersama menggunakan sistem operasi LINUX pada komputer server, dikarenakan LINUX merupakan sistem operasi open source dan free licence, LINUX memiliki sistem keamanan yang unggul karena di desain multiuser, disamping itu LINUX juga lebih stabil sehingga lebih jarang terjadi crash dibandingkan Sistem Operasi Lain .

b. Manajemen Data

Rancangan manajemen data yang diusulkan mengacu pada sistem desentralisasi data, yakni setiap bagian pada menu e-academic memiliki admin yang berbeda, sehingga setiap admin dapat menginputkan data masing-masing, namun untuk setiap admin hanya dapat melihat data / informasi yang telah diinputkan oleh admin yang berbeda. Hal ini dilakukan agar efektivitas dan efisiensi sebuah sistem dapat tercapai dengan mudah.

c. Aplikasi

Aplikasi e-academic Politeknik Harapan Bersama dibangun dengan menggunakan bahasa pemrograman PHP dan framework CodeIgniter serta database My SQL. Adapun tampilan e-academic Politeknik Harapan Bersama adalah sebagai berikut :

Gbr. 1 Kerangka Penelitian 


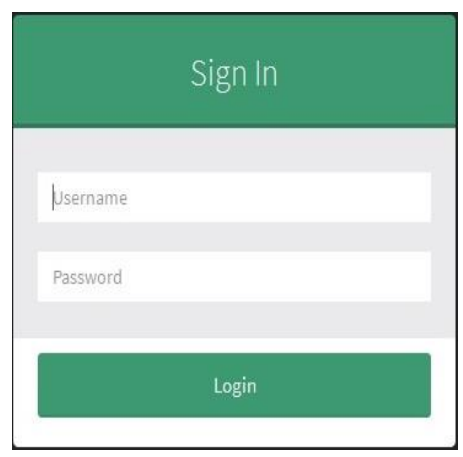

Gbr. 3 Menu Log In Admin
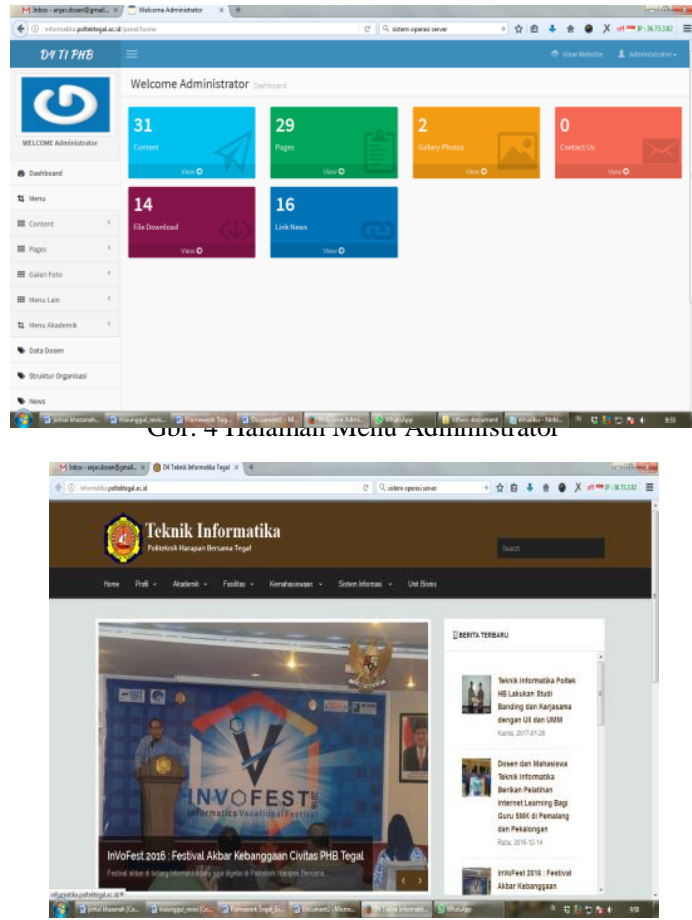

Gbr. 5 Halaman Menu Utama

\section{d. Perangkat Keras}

Pada penelitian ini, sebuah e-academic direncanakan agar setiap administrator pada Politeknik Harapan Bersama bisa menginputkan data akademiknya masing-masing, sehingga penyampaian informasi dapat terdistribusi dengan baik. Dalam hal ini pendukung perangkat keras untuk e-academic yang dibutuhkan adalah sebagai berikut :

1. Komputer yang digunakan sebagai server untuk sistem e-academic pada Politeknik Harapan Bersama

2. Komputer yang digunakan sebagai database server untuk sistem e-academic pada Politeknik Harapan Bersama

3. Komputer yang dijadikan administrator di setiap bagian website e-academic

4. Kabel UTP Enhanced Category 5 untuk menghubungkan administrator ke switch dan server ke database server

5. Konektor : RJ 45
6. Switch yang mendukung konektor RJ 45, NIC (Network Interface Card) dan UPS.

7. Bridge yang digunakan untuk memecah jaringan

8. Router yang berfungsi sebagai pengatur rute paket data jaringan

\section{e. Komunikasi}

Rancangan komunikasi yang diusulkan adalah dengan menggunakan jaringan internet. Internet atau interconnected network adalah sebuah sistem komunikasi global yang menghubungkan komputerkomputer dan jaringan-jaringan komputer di seluruh dunia. Internet mengacu kepada istilah untuk menyebut sebuah jaringan, bukan suatu aplikasi tertentu, oleh karena itu internet tidaklah memiliki manfaat apapun tanpa adanya aplikasi yang sesuai [14].

f. Komputasi Pemakai

Sebagai institusi pendidikan yang dituntut untuk menghasilkan kinerja yang baik, Politeknik Harapan Bersama sampai saat ini selalu mengikuti perkembangan teknologi yang semakin pesat. Ketersediaan komputer yang sudah terhubung dengan jaringan internet sebanyak 40 unit dan terdapat 12 unit yang belum terhubug ke internet. Diantara komputer tersebut rata-rata sudah mempunyai spesifikasi Core i3 walaupun masih ada beberapa yang menggunakan Dual Core. Oleh karena itu komputer merupakan suatu hal yang dianggap sebagai kebutuhan dalam bekerja di Politeknik Harapan Bersama.

g. Keamanan

Penggunaan firewall merupakan suatu keharusan pada pengamanan jaringan di Politeknik Harapan Bersama. Firewall merupakan sebuah perangkat lunak (Software) atau perangkat keras (Hardware) yang menyaring seluruh lalu-lintas data (traffic) antara komputer, jaringan komputer di rumah atau di kantor dengan Internet [15].

Dikarenakan pada penelitian ini pengusulan sistem operasi menggunakan LINUX, maka firewall yang diusulkan adalah dengan menggunakan IPTables. IPTables merupakan suatu tools dalam sistem operasi LINUX yang berfungsi sebagai alat untuk melakukan filter terhadap lalu lintas data [16]. Beberapa keunggulan IPTables diantaranya : mampu menginspeksi paket serta bekerja dengan ICMP dan UDP sebagaimana koneksi TCP, menyederhanakan perilaku paket-paket dalam melakukan negoisasi built in chain, mampu untuk memfilter flag-flag, opsi TCP serta address-address MAC.

Disamping itu untuk melindungi semua infrastruktur SI/TI dari virus, spam, dan malware, digunakan kombinasi instalasi terhadap anti-virus, anti-spam, dan anti-malware baik pada server sendiri, maupun pada setiap client. Disarankan untuk menggunakan anti-virus yang bersifat client/server atau server manageable, sehingga workstation hanya perlu meperbaharui melalui server, tidak perlu melalui internet. Selain itu anti-virus client/server lebih 
memudahkan administrator jaringan untuk menginstalasi maupun mengelolanya secara remote.

\section{B. Implementasi}

Berdasarkan atas ketujuh area tersebut maka dapat dibuatkan suatu konfigurasi teknologi konseptual. Konfigurasi teknologi tersebut akan memberikan pedoman bagaimana cara memanfaatkan sebuah $E$ Academic Pada Politeknik Harapan Bersama secara maksimal. Adapun bagan model konfigurasinya adalah sebagai berikut :

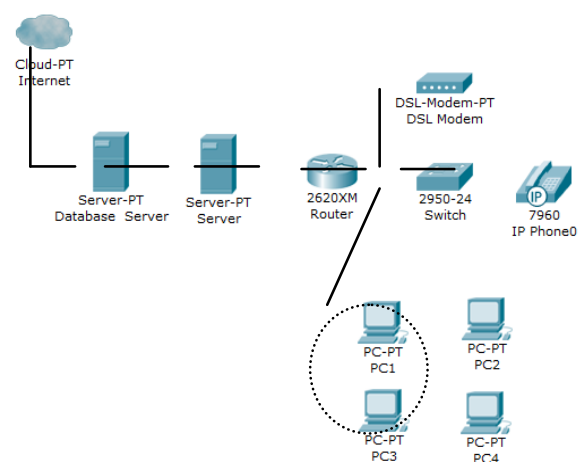

Gbr. 6 Rancangan Model Konfigurasi Arsitektur E-Academic Politeknik Harapan Bersama

\section{KESIMPULAN}

Berdasarkan pada penelitian yang telah dilakukan, maka dapat diambil beberapa kesimpulan sebagai berikut :

a. Pemodelan Enterprise Architecture framework TOGAF akan dapat menghasilkan blue print pada sebuah $e$-academic yang terintegrasi.

b. Pemodelan Enterprise Architecture framework TOGAF akan mempercepat proses pendistribusian informasi sehingga lebih efektif dan efisien.

c. Dengan memanfaatkan model Enterprise Architecture framework TOGAF, maka EAcademic Politeknik Harapan Bersama akan memenuhi kriteria reasoned, cohesive, adaptable, technology independent, domain neutral, dan scalable. Namun hanya satu kriteria yang tidak terpenuhi yakni kriteria vendor independent, artinya E-Academic dalam pengembangan selanjutnya dan tergantung pada pengembang sistem (vendor).

\section{REFERENSI}

[1] Sasmito, Ginanjar Wiro dkk. 2015. Implementasi Sistem E-Academic Politeknik Harapan Bersama Dengan Metode System Development Life Cycle. JIK : Jurnal Ilmu Komputer. Lembaga Penerbitan Universitas Esa Unggul

[2] Sasa, A., Krisper, M., 2010. Analytical models for the business and information architecture. Applied informatics XVIII
[3] Wilkinson, M., 2006. Designing an 'adaptive' enterprise architecture. BT Technology Journal 24, 81-92

[4] Jonkers, H., Lankhorst, M., ter Doest, H., Arbab, F., Bosma, H., Wieringa, R., 2006. Enterprise architecture: management tool and blueprint for the organisation. Information Systems Frontiers 8, 63-66.

[5] Sofian, Lusa., Dana,Indra,S., 2011. Kajian Perkembangan dan Usulan Perancangan Enterprise Architecture Framework. SNATI : Yogyakarta. ISSN : 1907-5022

「61 Harrison R. 2007. TOGAF Version 8.1.1 Edition Study Guide, New York : Van lishing

Ria. 2016. Analisis Penerapan Enterprise Pada Bagian Akademik Tinggi (Studi kasus STMIK Bumigora Indonesian Journal on Networking and Volume 5 No 2 - Mei 2016

Jny dkk. 2015. Penyusunan Enterprise re Planning Menggunakan Togaf Pada uhan Indonesia Iii (Persero). JSIKA . 1. Tahun 2015

Ginanjar.Wiro. 2013. Annual Performance Planning Information System With Enterprise Architecture Modelling The Secretariat Of The Central Java Province Parliament Used Framework Togaf. International Journal of Social Science and Humanity, Vol. 3, No. 4, July 2013

[10] Manolita, Rahayu. 2016. Perancangan Business Architecture Untuk Fungsi Akademik Pada Institut Xyz Menggunakan Framework Togaf Adm Studi Kasus Sistem Informasi Akademik (Siakad). Vol 3 No 01 (2016): Jurnal Rekayasa Sistem \& Industri

[11]Fahrianto, Feri Dkk. 2015. Perencanaan Infrastruktur Teknologi Informasi Di Lembaga Penelitian (Lemlit) Uin Syarif Hidayatullah Jakarta Menggunakan Togaf ArchitechtureDevelopment Method (Adm). Jurnal Teknik Informatika Vol. 8 No. 2 Bulan Oktober 2015

[12]Priyono, Harun AA. 2003. Perancangan Sistem Informasi Jabatan Fungsional Badan Litbang Pertanian. Jurnal Informatika Pertanian 12:31-44

[13]Setiawan EB. 2009b. Perancangan Strategis Sistem Informasi IT TELKOM untuk menuju World Class University. Di dalam: Seminar Nasional Aplikasi Teknologi Informasi; Yogyakarta, 20 Juni 2009. Hlm 97-101

[14]Iskandar. 2009. Panduan Lengkap Internet. Andi : Yogyakarta

[15]Brian Komar. Ronald Beekelaar. Joern Wettern $\mathrm{PhD}$, Firewalls For Dummies $2^{\text {nd }}$ Edition, Willey Publishing Inc. , New York, 2003

[16]Rash, Michael. 2007. Linux Firewalls. William Pollock Publishing 